Journal of Engineering and Science Research 2 (6): 01-06, 2018

e-ISSN: 2289-7127

(C) RMP Publications, 2018

DOI: $10.26666 / \mathrm{rmp} . j e s r .2018 .6 .1$

\title{
Development of Neo-Ptero Tailless Micro Aircraft
}

\author{
N. I. Ismail ${ }^{1}$, Mahadzir M. M. ${ }^{1}$, Hasnul $A^{2}$, M. Arif Alias ${ }^{1}$, A. A. Shariffuddin ${ }^{3}$ \& N.I. Kamel ${ }^{3}$ \\ ${ }^{1}$ Faculty of Mechanical Engineering, Universiti Teknologi Mara (Pulau Pinang), Kampus \\ Permatang Pauh, 13500 Permatang Pauh, Pulau Pinang, Malaysia. \\ ${ }^{2}$ Faculty of Industrial Design, Universiti Teknologi Mara (Kedah), Merbok, Kedah, Malaysia. \\ ${ }^{3}$ IFCON Technology (M) Sdn. Bhd, Taman Industri Meranti Jaya, 47120 Puchong, Selangor.
}

\begin{abstract}
Unmanned air vehicles (UAV) have been used for many years and it mainly focus on military purposes. Numerous UAV development have been popular worldwide because the low in development cost, operating cost and ability to provide accurate surveillance information and it is a better option for performing reconnaissance missions in hostile environment. However, in the past years a new type of UAV has appeared that possessed lighter weight and smaller in size and it is categorized as a micro unmanned air vehicle ( $\mu$-UAV). Although the nonautonomous ready-to-fly tailless $\mu$-UAV exists among local universities, the development of non-autonomous ready-to-fly tailless $\mu$-UAV is still open to be explored. Thus, this project demonstrates the development of the non-autonomous ready-to-fly tailless $\mu$-UAV named as Neo-Ptero. A special CNC hot wire cutter machine was used in the Neo-Ptero fuselage and wing development in which has evidently produced high accuracy of shapes and geometry based on the CAD design. A 3D printing process was used to produce few parts in the Neo-Ptero $\mu$ UAV model. The model was equipped with on shelves RC components for future flight testing purpose. The actual Neo-Ptero weigh around $1.3 \mathrm{~kg}$ and has a wingspan of $120.6 \mathrm{~cm}$.
\end{abstract}

Key words: Neo-Ptero $\mu$-UAV, micro unmanned air vehicle

\section{INTRODUCTION}

Tailless Micro Aircraft or also known as Micro Unmanned Air Vehicle ( $\mu$-UAV) is an aircraft controlled by an operator on the ground by using a handheld radio transmitter. The principle of $\mu-\mathrm{UAV}$ is the control of the aircraft is done by transmitting and receiving of signal which are done by the transmitter and receiver. The transmitter and receiver communicate to each other based on the input from the operator and the servo mechanism act upon the input to move the control surfaces. There are 2 types of wings in $\mu$-UAV which are fixed wing and rotary wings[1]. Fixed wing $\mu-U A V$ is commonly use in surveying [2] and mapping missions [3] because the simple structure of it allows for longer flight durations at higher speed whereas rotary wing is more complicated and possess higher maintenance cost.

The fixed wing $\mu$-UAV can be classified into 2 classifications which are tailless $\mu-\mathrm{UAV}$ and conventional $\mu$-UAV with tail. The weight of $\mu$-UAV can be up to $20 \mathrm{~kg}$ and it all depend on the functionality of the $\mu-U A V$ and the wingspan can be as long as $2 \mathrm{~m}[4]$. The extensive use of tailless $\mu$-UAV can be seen in developed country such the United States to survey and monitor the border between the neighbouring country. Tailless $\mu-\mathrm{UAV}$ is a popular option among mapping and surveillance company because of its advantages as the weight is lighter and the drag is minimized for better operating cost.

There are numerous numbers of tailless $\mu-\mathrm{UAV}$ in the market such as X8, KS-1 and Datahawk. Datahawk is one of the most common tailless $\mu$-UAV and it is more preferable model among the others as it can act as agriculture drone, surveillance drone and industrial aerial mapping drone. The advanced functions and capabilities such as waypoint routing, $1.164 \mathrm{~m}$ wingspan, autopilot control and higher altitude operations made Datahawk $\mu$-UAV suitable for mapping and surveying missions. Although the nonautonomous ready-to-fly tailless $\mu$-UAVs are around us for many years, the development of non-autonomous ready-to-fly tailless $\mu$-UAV is still open to be explored. Thus, the main objectives of this project are to develop another ready-to-fly tailless $\mu$-UAV aircraft model named as Neo-Ptero. Neo-Ptero is tailless $\mu$-UAV aircraft model that previously design and proposed by M.A. Sabri[5] as shown in Figure 1. The Neo-Ptero

Corresponding Author: N.I. Ismail, Faculty of Mechanical Engineering, Universiti Teknologi MARA Pulau Pinang, Jalan Permatang Pauh, 13500 Bukit Mertajam, Pulau Pinang, Malaysia, 6 04-3823180 
model consists of fuselage and wings which were built by using CNC Foam Cutter at IFCON (M) Sdn Bhd. Some parts of Neo-Ptero model were built by using Zortrax M200 at Universiti Teknologi MARA Pulau
Pinang. The completed Neo-Ptero model was then equipped with standard electronic flight control components for flight testing proposed.

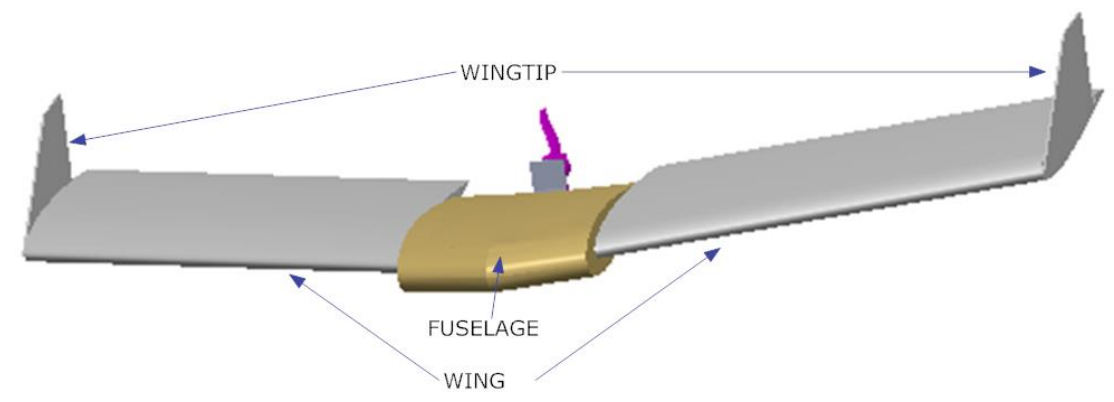

Figure 1 Neo-Ptero $\mu$-UAV proposed by M.A. Sabri[5].

\section{METHODOLOGY}

The basic parts of Neo-Ptero model includes the fuselage, wings and wingtips are already shown in
Figure 1. The CAD design of Neo-Ptero model was made in Solidworks software and orthographic view of Neo-Ptero model is depicted in Figure 2. The basic dimension of Neo-Ptero model is tabulated in Table 1.

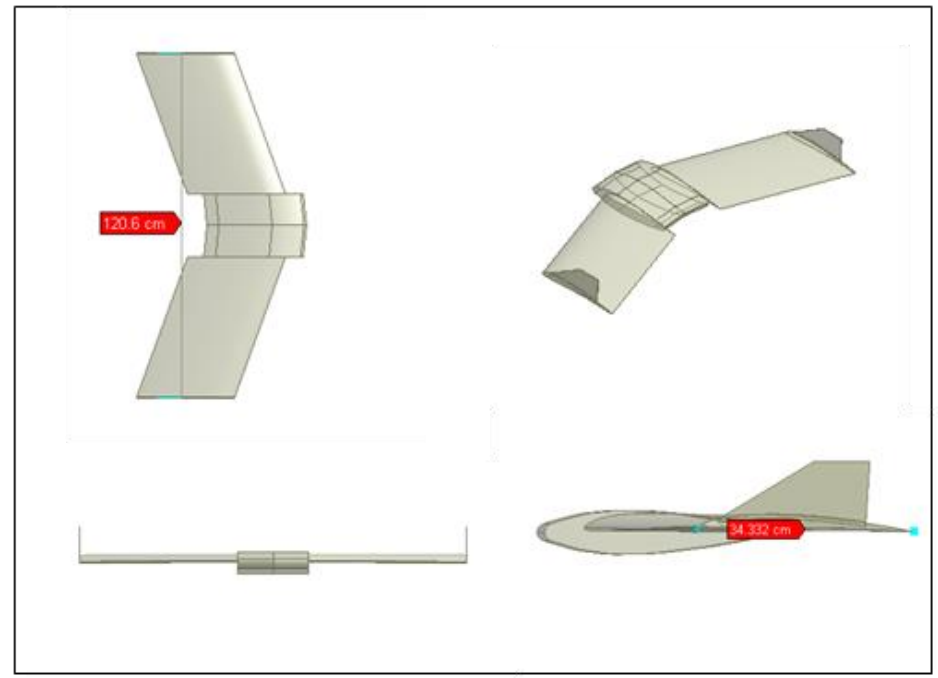

Figure 2 Oorthographic view of Neo-Ptero model

Table 1 Basic dimension of Neo-Ptero model

\begin{tabular}{c|c}
\hline Parameters & Dimension \\
\hline Gross weight & $1000 \mathrm{gm}$ \\
Wingspan & $120.6 \mathrm{~cm}$ \\
Chord Length & $26.76 \mathrm{~cm}$ \\
Total Wing area & $4208.65 \mathrm{~cm}^{2}$ \\
Aspect Ratio & 3.46 \\
Overall Fuselage Length & $34.837 \mathrm{~cm}$ \\
Wing airfoil type & NACA0012 \\
\hline
\end{tabular}

\subsection{Neo-Ptero Fuselage, Wings and connector parts fabrication.}

The wing and fuselage of Neo-Ptero model was fully develop by using CNC hot wire cutter machine at at
IFCON (M) Sdn Bhd, Puchong, Malaysia. The machine is a 4-axis CNC machine (shown in Figure 3) where it was capable of fabricating straight shapes as well as tapered shapes such as Neo-Ptero wing. Expanded Polyproplyene (EPP) foam was used for the Neo-Ptero 
fuselage and wings which is also compatible with CNC hot wire cutter machine. The machine operates based on temperature-controlled wire to melt the EPP foam material according to the CAD design and dimensions. EPP foam material is low density and possess high elasticity which means that the material is lightweight and the wings can witdhstand wingflex during flight

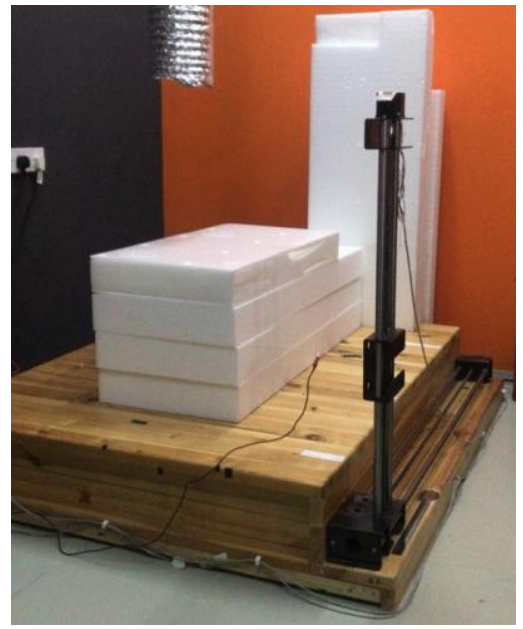

Figure $3 \mathrm{CNC}$ hot wire cutter machine at IFCON (M) Sdn Bhd.

Corrugated plastic (Corroplast) material was used to fabricate the wingtip and payload cover for the $\mu \mathrm{UAV}$ model. Corroplast is a light material and provide enough strength during flight. The wingtip was attached to the without fracture. The fuselage and wing parts produced by the CNC hot wire cutter machine is depicted in Figure 4. For the permanent fuselage-wings assembly, epoxy adhesive was used to attach the fuselage-wings parts. Epoxy adhesive provide tough and durable bond to the applied components to withstand impact during belly landing or crash.

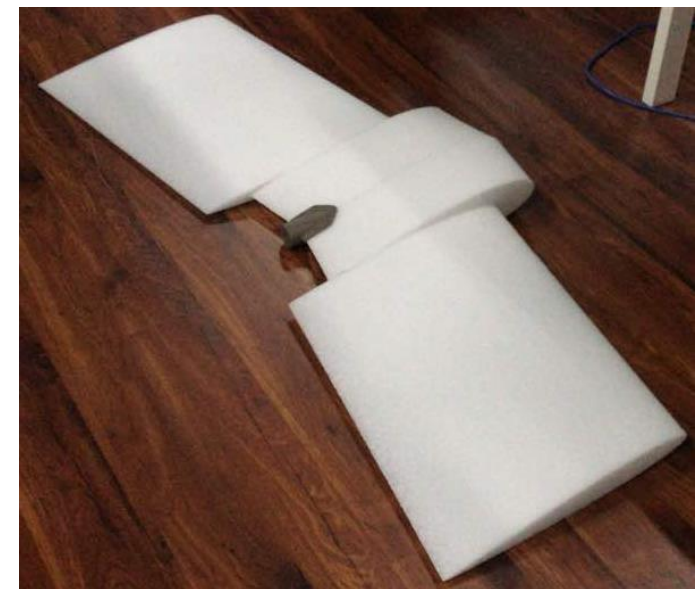

Figure 4 . The fuselage and wing parts produced by the $\mathrm{CNC}$ hot wire cutter machine.

wing by epoxy adhesive and the payload cover was assembled by using Velcro material to allow for detachable function. Figure 5 showed the wingtip and payload cover made from coroplast.
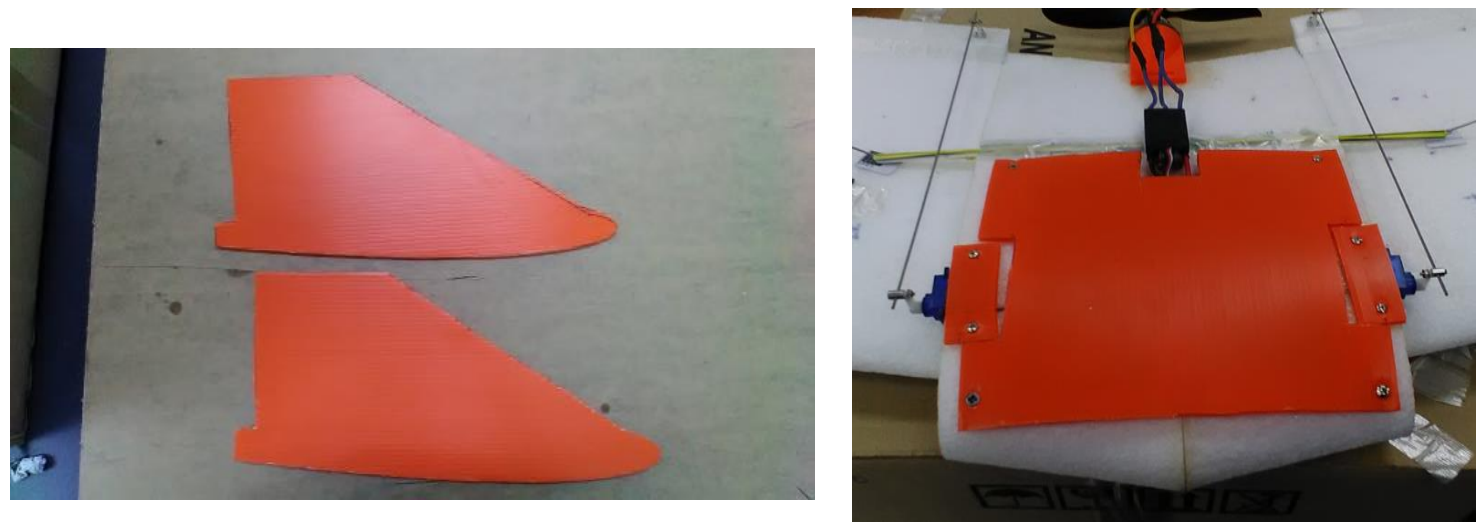

Figure 6 The wingtip (right) and payload cover (left) made from coroplast material.

$3 \mathrm{D}$ printing process was also involved in the fabrication of the connector components for Neo-Ptero $\mu$-UAV model. The wing connector and motor mount (shown in Figure 6) are samples of connecter parts that had been developed by using Zortrax M200 3D printer. The wing connector was used to connect fuselage and wing at the bottom section of $\mu \mathrm{UAV}$ while the motor mount was used as the connect between motor component with the fuselage. The ABS plastic material was used for the connector components to ensure the precision and reliability of parts for the Neo-Ptero development. 


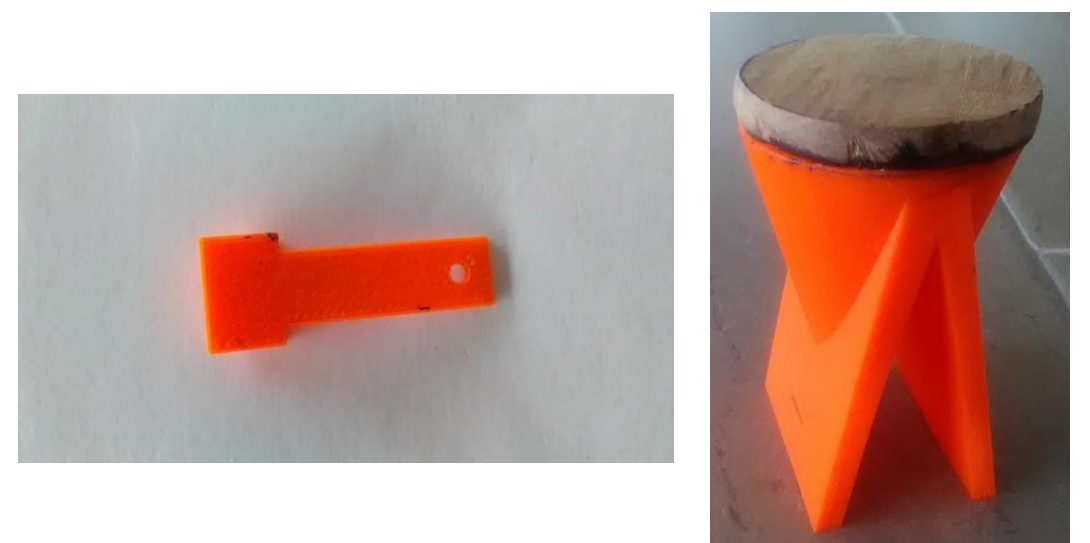

Figure 6 The wing connector (right) and motor mount (left) produced by Zortrax M200 3D printer.

\subsection{Electronics flight control components installation}

The electronic flight control components were installed on the Neo-Ptero $\mu$-UAV model for real flight testing purpose. The selection of remote-control (rc) components were done based on the requirement for the initial test flight. The selection of battery, electronic speed controller (ESC), motor and propeller were considered based on several factors such as the thrust generated and the maximum amperage from the motor and battery when choosing suitable ESC. Currently, the Neo-Ptero $\mu$-UAV used equipped with 40A ESC, 2.4 $\mathrm{GHz}$ transmitter, $1750 \mathrm{KV}$ brushless motor, $12 \times 6 \mathrm{e}$ propeller, $2200 \mathrm{mAh}$ battery and two 9g micro servo. The installation and location of all electronic flight control components are shown in Figure 7. The details of RC components installed on the Neo-Ptero $\mu$-UAV model is tabulated in Table 2.

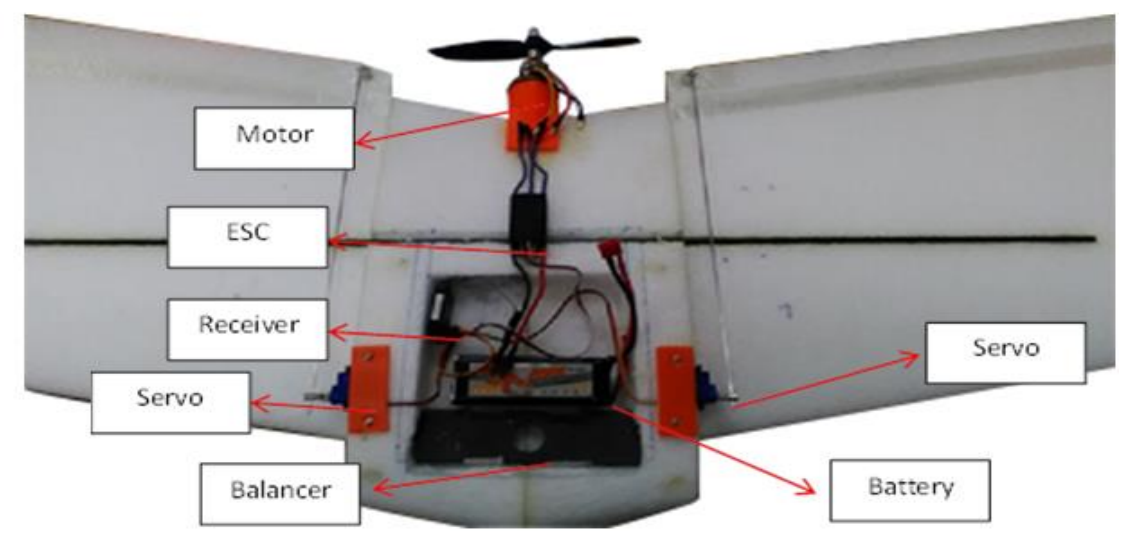

Figure 7 the location of all electronic flight control components

Table 2 RC components installed on the Neo-Ptero $\mu$-UAV model

\begin{tabular}{c|c}
\hline Components & Specifications \\
\hline Battery & 3 cell LiPo battery, $11.1 \mathrm{~V}, 2200 \mathrm{mAh}$ \\
\hline Transmitter and Receiver & 7 -channels remote control \\
& and $9.6 \mathrm{~g} 2.4 \mathrm{Ghz}$ receiver \\
\hline & Dimension $(23 \times 12.2 \times 29 \mathrm{~mm})$ \\
Micro servo & $1.8 \mathrm{~kg} / \mathrm{cm}(4.8 \mathrm{v})$ \\
& POM gear set \\
& $0.1 \mathrm{sec} / 60 \mathrm{degree}(4.8 \mathrm{v})$ \\
& $0^{\circ} \mathrm{C}-55^{\circ} \mathrm{C}$ \\
& $4.8 \mathrm{v}$ \\
\hline
\end{tabular}




\begin{tabular}{c|c}
\hline ESC & $40 \mathrm{~A}$ \\
\hline Motor & $1750 \mathrm{KV}$ \\
& maximum thrust $=17.0105 \mathrm{~N}$ \\
\hline Propeller & 12 -inch $\times 6 \mathrm{e}$ \\
\hline
\end{tabular}

\subsection{Flight control surface}

An elevon surface control is a special control surface that adopted for the Neo-Ptero $\mu$-UAV model. Figure 8 showed the location of elevon control surface for the Neo-Ptero $\mu$-UAV model. That kind of control surface normally found in similar tailless aircraft such as delta wing aircraft and flying wing. Elevons for the Neo-Ptero $\mu$-UAV model are located at the trailing edge of the wings. Aircraft pitching and rolling motions are controlled by the combination movement between the left and right elevons based on the pilot's input. The elevon control surface was created by removing several millimeters of material at the bottom trailing edge of the wing. Only a thin layer of material was left on top to ensure the elevon was still attached to the wing. Adhesive tape was layered on top of the wing along the cutting zone to avoid structure failure.

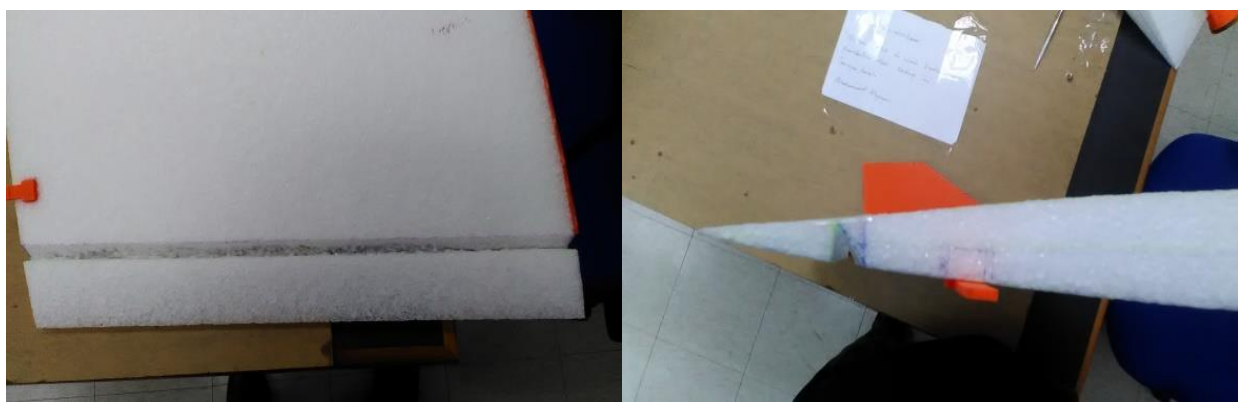

Figure 8 Elevon control surface for the Neo-Ptero $\mu$-UAV model

\section{RESULTS}

The complete assembly of Neo-Ptero $\mu$-UAV model is shown in Figure 8. Based on the overall dimension, one can presume that the actual model has almost similar dimension with the 3D CAD dimension.

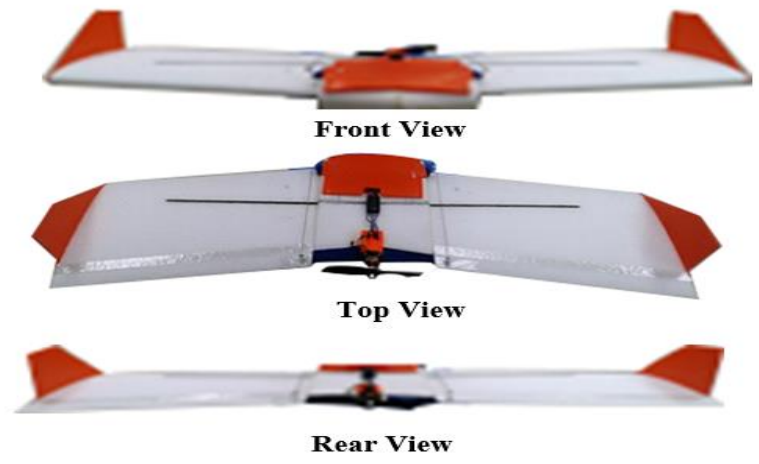

The actual wingspan, chord and fuselage length were precisely measured at $120.6 \mathrm{~cm}, 26.8 \mathrm{~cm}$ and of $34.8 \mathrm{~cm}$, respectively. This dimension showed the $\mathrm{CNC}$ hot wire cutter precisely produced the fuselage and wing parts. The motor mount produced by the $3 \mathrm{D}$ printer has also fits perfectly with the fuselage part.

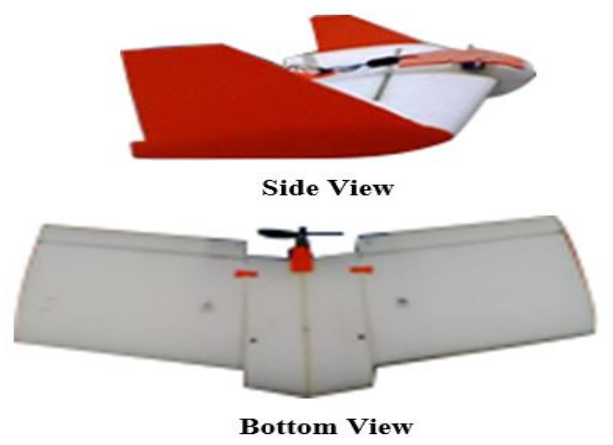

Figure 7 Final assembly of Neo-Ptero $\mu$-UAV model

Despite the precision found in the overall aircraft dimension, the actual Neo-Ptero model has been overweight at $1.3 \mathrm{~kg}$. This overweight magnitude (> 1 $\mathrm{kg}$ ) is expected due to balancer component installed at the payloads compartment (refer to Figure 7) to provide the longitudinal stability on the aircraft. The balancer itself contributed about 25\% (325 grams) from overall aircraft weight. Other than that, the excessive use of 
epoxy adhesive at the fuselage-wing and wing-wingtips joints has likely contributed to the weight increase of the Neo-Ptero $\mu$-UAV model. The amount of epoxy applied to the attachments may have increased the model weight.

Based on initial control surface testing, the elevon was able to deflect upward and downward as intended. However, the deflection rate was low since the whole elevon part was not deflected at the same angle due to surface deformation. The highest deflection angle for upward movement was around $60^{\circ}$ but the angle decreased as the part closer to the wingtip. The highest elevon deflection angle for downward movement is marked at $10^{\circ}$ but the angle decreases as the part closer to the wingtip.

\section{CONCLUSION AND RECOMMENDATION}

The non-autonomous-ready-to-fly Neo-Ptero $\mu$-UAV model was completely developed to provide another type of micro UAV model. The actual NeoPtero weigh around $1.3 \mathrm{~kg}$ and has a wingspan of $120.6 \mathrm{~cm}$. The development of Neo-Ptero fuselage and wing involves a special $\mathrm{CNC}$ hot wire cutter machine which evidently produced high accuracy of shapes and geometry based on the CAD design. 3D printing process was also involved in the few components of Neo-Ptero $\mu$-UAV model such as the motor mounting. The model was then installed with RC components for future flight testing purpose. Despite the precision found in the overall aircraft dimension, the actual Neo-Ptero model has been overweight at $1.3 \mathrm{~kg}$. This is due to balancer component which needed to provide the aircraft stability. Control surface testing also shows that the elevon was able to deflect upward and downward as intended. However, the deflection rate still need further improvement due to control surface deformation. In future works, a static thrust testing will be conducted to ensure the motor have sufficient amount of thrust for real flight testing purpose.

\section{ACKNOWLEDGEMENT}

Authors acknowledge technical and financial support from Universiti Teknologi MARA Cawangan Pulau Pinang and the Government of Malaysia. A special gratitude also given to the IFCON (M) Sdn Bhd, whose contribution in the funding the aircraft fabrications works and helped authors in writing this paper.

\section{REFERENCES}

[1] P. J. Hardin and R. R. Jensen, "Small-Scale Unmanned Aerial Vehicles in Environmental Remote Sensing: Challenges and Opportunities," GIScience \& Remote Sensing, vol. 48, no. 1, pp. 99-111, Jan. 2011.

[2] P. E. I. Pounds, "Paper Plane: Towards Disposable Low-Cost Folded CelluloseSubstrate UAVs," in Australasian Conference on Robotics and Automatio, 2012, pp. 3-5.

[3] R. J. Bachmann, R. Vaidyanathan, F. J. Boria, J. Pluta, J. Kiihne, B. K. Taylor, R. H. Bledsoe, P. G. Ifju, and R. D. Quinn, "A Miniature Vehicle with Extended Aerial and Terrestrial Mobility," in Flying Insects and Robots, D. Floreano et al., Ed. Berlin, Heidelberg: Springer Berlin Heidelberg, 2009, pp. 247-269.

[4] J. Blondeau, J. Richeson, D. J. Pines, and A. Norfolk, "Design, Development and Testing Of A Morphing Aspect Ratio Wing Using An Inflatable Telescopic Spar," American Institute of Aeronautics and Astronautics, vol. 1718, no. April, pp. 1-11, 2003.

[5] M. A. Sabri and N. I. Ismail, "An Aerodynamics Performance On Micro Unmanned Air Vehicle Wing," Faculty of Mechanical Engineering, Universiti Teknologi Mara (Pulau Pinang), 2017. 